British Journal of Chinese Studies, Vol. 9 (2), July 2019

ISSN 2048-0601

(C) British Association for Chinese Studies

\title{
Confessions of a Dance Hostess: \\ Social Dancing in Shanghai and Self-Portrayals of Hostess-Writers, 1930-1949
}

Amanda Zhang

University of Oxford

\begin{abstract}
This paper adds to the existing scholarship on republican Shanghai and the study of social dancing, and dance hostesses, during that period. The key to this revision is the examination of the self-portrayals of hostess-writers throughout the 1930s and up to 1949. Hostess-writers documented their lives and careers as dance hostesses by writing about and publishing topics that ranged from politics to aspirations and personal tragedies. These writings were produced against a tumultuous political backdrop of war and nation-building, a period when social dancing blossomed in China as a popular entertainment option for people of different social classes. This paper considers the agency of dance hostesses before and after the Sino-Japanese War. It argues that they actively sought to mediate their existence through the power of narration that best suited their personal and financial interests.
\end{abstract}

Keywords: dance hostesses, social dancing, Shanghai, self-portrayals.

\section{Introduction: The Articulation of Self in the Writing of Hostess-Writers}

On the evening of June 24, 1938, a sickly woman named Wang Qinzhen (王琴 珍 b. 1925) returned home after a long night out at the Paramount Ballroom (Bailemen wuting 百樂門舞廳), where she was one of the most popular dance hostesses. Upon arrival, her face was as pale as snow. When questioned by her concerned mother, she uttered nothing but vaguely pointed at her throat. She was sent to hospital, and this failed suicide attempt was only one of several known (Wufeng, 1938a: 1). Despite her seemingly fragile emotional state as demonstrated by her attempts to end her life, Wang's writings showed strength, patriotism and independence, as well as the determination and resilience to 
fight on, whatever fate threw at her. She wrote frequently and her ability to write fluent prose earned her the title of "Best Writer in the World of Dance" (wuguo diyi zhi bi 舞國第一支筆) (Shidai, 1939: 41-42). Her writings reveal an emancipated female personality and exert a powerful textual presence that helped build her reputation and fame within and outside the walls of the Paramount. However, she was not the only hostess-writer in republican Shanghai; some others also wrote columns documenting their careers and lives.

The social dancing scene with its dance hostesses was an important feature of republican Shanghai. In a comprehensive guidebook of Shanghai published in 1934, the phenomenon of dance halls and social dancing was described as a new but popularised form of entertainment originating from the West (Shen, 1934: 151-153). Another guidebook derided dance halls as "kilns that melted gold" and as responsible for the moral decay of many young people (Wang, 1947: 186). Narratives of the dance hostesses noted their modern clothing, beauty, liberal attitudes and their frequent encounters with romance (Wufeng, 1938i: 10). Dance hostesses such as Wang Qinzheng also took every opportunity to present themselves as both personality and consumer item. Part and parcel of this self-commodification process involved documenting their lives and careers as professional dance hostesses by writing about and publishing topics that ranged from politics and nationalism to hopes and personal misfortunes. These writings were created against a tumultuous political backdrop of war and nation-building, a period when social dancing blossomed in China as a popular entertainment option for people of different social classes.

This paper considers the agency of dance hostesses during the republican period through a study of the self-portrayals of hostess-writers. It argues that dance hostesses actively sought to mediate their existence through the power of narration that best suited their personal and financial interests. While they were not always in control, they were not totally trapped in a hostile and unstable political climate, unable to control or change at least some aspects of their fate.

Several scholars have examined the history of social dancing and dance hostesses in Shanghai. Specifically, Ma Jun's 馬軍 pioneering and comprehensive work on these topics illustrates the rise and decline of social 
dancing, and how it was eventually banned after the Sino-Japanese War. Ma argues that dance hostesses were not proactive political actors, even though the issue of social dancing and dance hostesses became a political matter. Ma describes these women as “ordinary folks" (xiao baixing 小百姓). In his book, he illustrates how many women were forced by various circumstances to take to the streets in 1948, and that many of them were just ordinary women trying to get on with their lives until they were caught up in politics (Ma, 2005: 187). Andrew David Field furthers Ma's work by arguing that dance hostesses were considerably affected by the political situation in republican Shanghai, particularly when Confucian conservatism eventually prevailed and gave way to the anti-dance movement. As such, Field also sees dance hostesses as relatively passive in that their security and fate were to a large extent dependent on discourses and political realities beyond their control, even though Field notes that dance hostesses, such as Wang Qinzhen, wrote articles for journals about social dancing (Field, 2010: 184, 261).

If, however, we investigate the writings of these of hostess-writers, we discover how they were, at least on some occasions, willing participants in politics and actively strived for change. They tried to advance their interests by portraying themselves to their advantage, and responding to other narratives written by concerned social and political agents (Dazhong, 1944: 49-57). In other words, dance hostesses were not completely passive, but contributed to shaping their image in times of war, and political and social turmoil.

Regarding dance halls and social dancing in China, both Ma Jun and Andrew David Field have described how social dancing was a relatively new phenomenon in republican Shanghai. Dancing in China had its roots in the early dynasties as a form of art, ceremonial ritual and entertainment. Social dancing, however, an activity which involved intimate physical interaction between men and women, was brought to China by Westerners and remained an exclusively Western and elitist activity that continued throughout the 1920s (Ma, 2005: 12). Both $\mathrm{Ma}$ and Field have also written about how the Black Cat Cabaret was established by Chinese investors in December 1927, and thus became the first dance hall in Shanghai to employ its own group of dance hostesses (Ma, 2005: 2; Shenbao, 1927: 1). Within a year, there were more than 33 dance halls in business, including the Majestic Hotel (Ma, 2005: 2). 
Both $\mathrm{Ma}$ and Field's works also illustrates how the demographics of dance hostesses changed. While they were primarily Russian and Jewish refugees in the early years of social dancing, Chinese women later constituted the majority of dance hostesses in Shanghai, particularly after social dancing became a regular activity for Chinese consumers. In January 1941, while a few dance halls such as the Casanova and Jose Bar had exclusively Russian dance hostesses, most dance halls in the French Concession had a combination of Russian, Jewish and Chinese dance hostesses ( $M a, 2005:$ 11; Field, 2013: 21). There were even dance halls such as the Charleston and Ladybird, which had only Chinese dance hostesses (Shanghai Municipal Archives (hereafter SMA), U38-1-2060). These statistics altered greatly a few years later. In 1946, out of 1,622 dance hostesses surveyed, only 36 were Russian, while 9 were Italian and 3 Korean. The remainder were Chinese women from Shanghai, Jiangsu, Zhejiang and Guangdong, with an occasional few from locations such as Shandong and Hubei (SMA, Y3-1-58-151).

As social dancing became a common popular pastime in Shanghai, professional dance hostesses became a well-known group of people, with the more famous and popular of them considered to be semi-celebrities with their own followings. It is difficult to attribute these dance hostesses to a particular social or political class. Their profession required them to be elegantly dressed in clothes of the latest fashion, and to behave like glamorous, liberated, modern women. Indeed, they were largely admired for these outward qualities. While some of them appeared to live extravagant lifestyles, frequenting luxury hotels and restaurants and wearing expensive silk dresses and furs, many others lived in poverty and struggled to put food on the table for their families and themselves. They were also from a range of backgrounds. While some of them were from rural areas and farming communities in China, others had been city dwellers since birth (SMA, Y3-1-58-151). Thus, while the appearance of glamour was only part of their outward appearance, behind this lay familial burdens and responsibilities that were shared by most ordinary working women in republican China.

As demonstrated by scholars such as Ma and Field, besides the money dance hostesses sent to their families, the largest item of monthly expenditure for an average dance hostess was clothing, which is indicative of their efforts to keep 
up their outwardly glamorous appearance (SMA, D2-0-2748-8). Dance hostesses, however, were not generally known for their academic excellence or ability to compose beautiful prose and poetry. Most did not receive a good education, if any at all. Although there were the occasional few who were publicly celebrated for their university education and background, most dance hostesses were illiterate or had received only primary school-level education (SMA, Y3-1-58-151; Q141-5-41; Q137-7-33). Despite this, some of those who were literate, wrote and published in newspapers and periodicals as a way of increasing their personal or collective publicity.

Furthermore, although some men in China had assumed a female voice to write as women, it can be assumed here that these hostess-writers were women. This is because some of them, such as Wang Qinzhen and Li Li 李麗, were well-known dance hostesses who had a relatively strong media presence. They gave interviews in periodicals and newspapers quite frequently. Moreover, the ways in which members of the public and editors of periodicals responded to these self-portrayals also support the view that these hostesswriters were female.

Since this paper primarily investigates dance hostesses, it is also in conversation with existing scholarship about the modern woman in republican China. This is because dance hostesses were seen as modern women, and the dance hall was a site of modernity and a necessary backdrop for the emergence of the modern Chinese woman (Lee, 1999: 23-29). The modern woman was a symbol of Chinese modernity during the republican period, and several scholars have examined her as an archetype of the Chinese woman by looking at the discourse about them. Leo Lee suggests that the modern women portrayed in the fictional works of republican writers such as Mu Shiying 穆時英 (1912-1940) takes a dominant role over men, and although they are objects of male erotic desires, these women also have the ability to return the male gaze indignantly (Lee, 1999: 28). Louse Edwards argues that the discourse about the policing of the modern woman during the republican period consisted of synecdochal discussions about the governance of the Chinese (Edwards, 2000: 115). Madeline Yue Dong examined the discourse about modern women in republican magazines and newspapers, and argues that the modern woman was feared because her attractiveness, and the inability of men to resist her, 
destabilised existing gender relations in China and brought changes to the patrilineal family order (Dong, 2008: 217). Similarly, Sara E. Stevens argues that the modern girl and the new woman were two new paradigms evident in republican China, that embodied both the hopes and fears attendant on modernity (Stevens, 2003: 82-103).

These arguments are all relevant here, as this paper also looks at narratives and discourses on the modern Chinese woman. It, however, furthers existing work on this archetype by focusing on the self-representations of modern women who were from a lower-class background. Specifically, this paper looks at how these modern women chose to represent themselves instead of how they were represented by other men and women, and thus offers new insights concerning the agency of the modern woman in republican China. They were not completely oppressed or totally emancipated, but as this paper shows, their condition was somewhere in-between.

\section{A Vision of Glamour and Victimhood: Self-Portrayals by Hostess-Writers before the Sino-Japanese War}

Dance hostesses who were literate wrote about themselves and their lives when they could. These narratives were beneficial on two levels: for the individual, they resulted in fame and reputation; collectively, they increased group recognition and social status. These individual and collective benefits were intertwined and mutually dependent. Thus, dance hostesses portrayed themselves as liberal, desirable women, but also occasionally as pitiful victims of circumstance, as a way to garner sympathy from the public. Hostess-writers sought to write because throughout their careers, one of the main problems they faced was a lack of public recognition. Furthermore, earning a living was of the utmost importance to this group of working women, particularly in the 1930s and 1940s. Dance hostesses in Shanghai, many of whom were refugees from neighbouring suburbs and rural areas, lived with the constant fear of losing their job and only source of income owing to a public backlash against social dancing. Not only could such a backlash deter people from seeking entertainment and hiring dance hostesses in dance halls, but also trigger a government ban on the operations of commercial dance halls. Thus, there was 
a need for dance hostesses to promote themselves, and the entertainment services they physically provided, whenever possible. All such services, from table-sitting to social dancing, were hirable (Shen, 1934: 139-141). In other words, the patron of a dance hall had to pay for the time and services provided by a dance hostess. She had to package and promote herself as a commodity that was capable of gaining the attention and approval of potential patrons and customers, and enticing them to purchase her services (Wode huabao, 1939: 5).

\section{Embracing Life as a Dance Hostess}

In many cases, dance hostesses portrayed themselves as liberal and modern women available for hire through public means of promotion. In light of differing public opinion regarding social dancing and the role of dance hostesses, hostess-writers had to promote themselves in an effective way that gained admiration and even support. This was particularly the case during the pre-war period, when many of these hostess-writers embraced their lifestyle as dance hostesses. Working as one appeared to be a better way of life compared to other options for some women.

Dance hostess Wang Lingyi 汪伶儀 didn't want to be married into a good family because of the fear of being "locked up" at home. Wang claimed that any woman with a bit of spirit in her would not be able to endure such oppression, and did not apologise for being a dance hostess. In any case, there were many women of higher social status who suffered much more than she did. This was because she felt that men and women did not have equal power in China. Wang was open about how she attracted and retained customers. She wrote in a magazine that she always told her customers she was eighteen. This was because they preferred this age to anyone older. She subsequently went on to say that her age depended partly on the customer. But this, argued Wang, was not because she was the plaything of men or subordinate to them. She wrote that if she said she was eighteen, then she was eighteen, and that age was entirely constructed by her (Shiritan, 1934: 14). As such, Wang presented herself as a strong, confident and liberal woman, qualities attributed to the "modern woman" who was much admired by the public during pre-war Shanghai. 
Hostess-writers demonstrated in their writings that these women valued freedom of choice and wished to exert control over their lives, all of which were qualities that suggest they were "modern women" and made them more desirable as a consumable item or service. Dance hostess Yin Zhu 隱答 was explicit in her attitude towards her job and men in another column. She wrote about one of her patrons, describing him as a laughable old man who came by with two tickets to a movie screening. She then took the tickets from him, ripped them into shreds and made it apparent that she clearly did not think much of him, calling him an idiot. But Yin wrote that she had to accommodate him and his wishes from time to time, because he was well off and she needed the money. She admitted that she lost her temper occasionally, which might seem inappropriate, but suggested that being slightly cranky at times demonstrated how precious she was (Funüjie, 1941: 19-20). In this case, Yin seemed fully engaged in her job and clearly understood ways in which to maximise her interests, despite the fact that she might not have willingly become a dance hostess in the first place.

\section{Softening One to Her Cause}

In certain cases, however, dance hostesses portrayed themselves as pitiful victims of life and circumstances. In return, this helped them earn sympathy and attract attention from the public. This was particularly the case when general narratives about social dancing were sometimes tainted by accusations of immorality and excessive splendour. Hostess-writer, Hu Manli 胡曼麗， documented how she became a dance hostess. She wrote that she was only a teenager when she began and, at first, had to work for eight hours every evening and danced so much that the muscles in her legs increased significantly in size. She claimed that it was difficult for her to earn much of an income, because she had to share half of what she earned every day with the dance hall. To maintain her glamorous appearance, she also had to buy expensive clothes and shoes which ate up a significant part of her income. Furthermore, she had to give most of what was left of her income to her family. For Hu, life was difficult as a dance hostess (Diansheng, 1935: 18). 
Hu's description of her job and lifestyle is similar to the stories of other dance hostesses, and these writings all emphasise the inadequacy of income. They demonstrate that the reality behind the perceived glamour and beauty was often poverty. One wrote that there was a misconception as to how much a dance hostess earned; people thought that such women enjoyed a good income (1935: 35). Most started their dancing career at a young age because of their family's lack of money. One was only 14 when she started. She was the eldest daughter, with three younger sisters and one younger brother. With high inflation in Shanghai, everything became too expensive and unaffordable for her and her family, particularly after her father lost his job. Her mother eventually found someone who helped her get into dancing school. Even though it was the only way out for her, dancing every evening was difficult. She said that just writing about her life at the dance hall made her feel immense pain and sadness (Diansheng, 1936: 30).

A similar, somewhat tragic story is echoed in the writings of Yang Qing 楊菁. Yang was only 16 when she met her future husband, and they married against the wishes of Yang's parents. Yang thought that she would have a sweet and happy life after marriage, but she was mistaken since her husband spent most of his time gambling, drinking, dancing and seducing girls while Yang stayed at home. Despite having wealthy parents and loving sisters, Yang couldn't return to her family home. She eventually divorced her husband and became a dance hostess as she had no income and no employable skills. Resentful about the life she had lived and about being a "plaything", she decided to take revenge on men in general. Now, she was able to use her experiences and what she had learnt in dance halls to control men. Yang admitted that her newfound purpose was to trifle with men (Funü shijie, 1943: 28-29).

Writing about motherhood and the sacrifices they had to make for their children was another way in which hostess-writers acquired sympathy. Zhang Meili 張美莉 described how she was a hardworking and responsible mother, forced by situations and unforeseen circumstances to become a dance hostess. Originally a teacher in Tianjin, Zhang came to Shanghai to pursue a similar career in teaching. After a few odd teaching and administrative jobs here and there, she married a man whom she later realised was a severe opium-addict. She claimed that while she immediately regretted her choice of husband, she was 
already pregnant and thus had to save her marriage by giving up all her savings to help her him quit his opium addiction. He, however, continued taking opium, frequenting brothels, and was even at times physically abusive. Eventually, Zhang left home with her two young children and finalised a divorce, but her former husband refused to pay alimony. Thus, she claimed that it was out of desperation and the need to take care of her children that she became a dance hostess (Yule, 1935: 465).

Besides narratives about how these women were forced into social dancing by tragic life circumstances, hostess-writers also wrote about the poor treatment they received from the men they met in dance halls. One wrote about how she was raped by her client, a young man who looked respectable, wore suits and appeared to be from an upper-class background. He showered her with affection, and spent a lot of money buying champagne and paying to dance and sit with her. This hostess-writer was initially smitten. She described how she was flattered by the amount of time he spent with her and the attention he gave her. She thought of herself as a mere dance hostess, but was pleasantly surprised that someone from an upper-class background would even notice her. Eventually, this hostess-writer was invited to go to a hotel room with him after work. Although she stated that she was very hesitant and sceptical, she nonetheless complied because he was her main client. After losing her virginity to this man, she wrote that she cried for days, saddened by what had happened to her, as well as realising that she was not treated as a human being, but was merely a plaything of men (Xiaojie, 1937: 14).

Occasionally, hostess-writers also wrote about their anxieties, especially those related to their careers as dance hostesses, which perpetuated the notion that they were pitiful victims. Hostess-writer Li Li wrote that social dancing was her lifeline, and that she could not reject a client's advances because it was her duty and responsibility to entertain him. Moreover, she felt very uncertain about what her life would be like in 10 years' time, and contemplated that it would be very sad if she was still a dance hostess by then. She stated that she was afraid that she might be laughed at and called out for having been a bad financial planner when she was younger, or for being too materialistic, thus deserving her life as a lowly dance hostess. According to her writings, thoughts about abandoning her money-oriented lifestyle went through her mind, but 
then again, she also realised that she could not abandon her career. Li argued that this was because people were materialistic, and that she lived in an acquisitive society, and thus had to fit in (Rensheng xunkan, 1935b: 14).

Furthermore, self-perpetuating narratives about the tragic lives of these women were successful in gaining the sympathy of some members of the public. Upon hearing the heart-rending story of one dance hostess who was first forced into the profession after her husband died, and then was brutally raped by one of her clients, one commentator argued that being a taxi dancer was not a lowly profession. He suggested that one should be sympathetic to those who had to make ends meet by doing such a job (Yingwu xinwen, 1935: 7). Another journalist also wrote about his encounter with one who told him about her poor upbringing, and how she was forced to seek a job as a dance hostess in order to make ends meet and earn money for her family. After their meeting, the journalist felt heavy-hearted, and argued in his column that he couldn't possibly be the only one who felt sympathetic towards these women (Tianwentai, 1936: $3)$. Consequently, a similar response from people who have read the selfportrayals of these hostess-writers can be inferred.

Amid mixed perceptions of dance hostesses and social dancing in general, it was in the interests of the hostess-writers to portray themselves in a way that attracted attention and sympathy, as well as admiration and support from the public. These women sometimes depicted themselves as desirable because of their liberal qualities, their new-found power and their ability to exercise freedom of choice. In certain cases, however, hostess-writers also portrayed themselves as victims of abuse and as hardworking mothers and daughters who were coerced by unfortunate circumstances into a career in social dancing.

\section{Narrating Wartime Pleasures: Hostess-Writers as Patriotic Women}

In light of the public backlash against social dancing and dance hostesses in particular, hostess-writers presented themselves as enlightened and patriotic women, willing and ready to make wartime contributions for their country. This was considered more appropriate and acceptable during wartime China, in contrast to the pre-war portrayals of glamour and sexual liberation. Such 
patriotic self-portrayals were also necessary for financial reasons. Living in wartime China meant earning a living was an even more pressing issue for many women, and dance hostesses struggled to improve their reputations by narrating their careers and identities in ways which could co-exist with rising nationalistic sentiments in wartime China (Wufeng, 1938d: 5-6).

War officially broke out between Japan and China in 1937. While parts of Shanghai and other parts of China were under fire, it was business as usual for the dance halls in Shanghai (Shenbao, 1938b: 10). A significant number of female refugees became dance hostesses while men spent money and leisure time in these venues (Wuying, 1938b: 9-10). Excessive hedonism and entertainment during wartime, however, seemed highly inappropriate and calls to cease the operations of the dance halls surfaced (Shenbao, 1943: 3). Moreover, dance halls did not discriminate against their guests so long as they were able to afford the goods and services offered. Hence, dance halls were visited by a range of guests, from Japanese military men to the usual groups of Western expatriates and Chinese patrons (Shenbao, 1938a: 2). Social dancing, dance halls and dance hostesses were increasingly disapproved of in view of China's wartime situation, particularly when frugality became an important determinant of patriotism. Thus, dance hostesses portrayed themselves as enlightened and patriotic women, who were willing and ready to make sacrifices for their country as a way to retain public support and to promote themselves.

\section{"The Best Writer in the World of Dance"}

One of the most prominent and well-known writers who successfully portrayed herself as a patriot and an ambitious hard worker was Wang Qinzhen, who was mentioned briefly at the very beginning of this paper. Wang was most active in writing during the years of 1938-39 (Shidai, 1939: 41-42). She depicted herself as both a keen student and a victim of war, who was forced to go into the social dancing business but worked her way up despite various hardships. Life as a dance hostess was not easy; Wang notes that she was much happier when she was younger, and that her early years as a dance hostess were miserable (Wufeng, 1938h: 22). Regardless, she claimed that she wanted to conquer life as she was still young, to make the most of what she had, and to help those in 
need (1938i: 10). As she claimed to have suffered the slings and arrows of misfortune, she said that she understood the suffering of mankind. Thus, her sympathy and understanding towards those who had suffered a similar fate motivated her to help others (1938c: 5).

Wang portrayed herself as a keen writer, even suggesting that one way to help others was through writing. This improved her image as education and literacy were considered to be traits of the modern woman. Despite her fulltime job as a dance hostess, however, she claimed that she continued her studies in women's vocational schools whenever possible. It was in these training schools that she learnt and improved her writing skills (Wusheng, 1938a: 7-8). She actively encouraged others to continue their pursuit of knowledge while working as dance hostesses, just like her. Wang's attitude towards life changed after coming across the phrase "where there is a will, there is a way" in a book, and it was then that she decided to study. While she didn't think that she was showing off, she thought that she was merely trying to prove that if one tries, and is willing to think, it would not be difficult to understand something. She then encouraged fellow dance hostesses to follow her example. Wang also proposed forming a study group of dance hostesses, where they could all discuss things they did not understand together, and "let those who despise us know that dance hostesses are also human beings, intelligent enough to examine academic issues" (Wufeng, 1938f: 28). Together, she further claimed, dance hostesses could continue their work to make ends meet while furthering their education for the sake of learning (1938f: 28). Such self-portrayals of herself as a keen student, and as someone who encouraged others, contributed to her increasing publicity.

While Wang enjoyed immense success in her dancing career and was an acclaimed writer of articles and prose, her private life was marred by a series of personal problems and failed relationships. Her first known and documented suicide attempt occurred in 1936, when she was still employed by the mid-tier Black Cat Cabaret. Her suicide attempts were briefly described in some gossip columns; they were allegedly caused by the death of her fiancé, a patron of hers, while she was working at the Liberty Dance Hall (Xiaoyao wuchang 逍遥舞場). Consumed by grief, it was claimed in tabloid papers that Wang attempted suicide multiple times by drinking poison. Soon after that, she went back to her 
career as a dance hostess (Tanxing nülang, 1936: 13-14). In 1938, she attempted suicide again, for reasons unknown to the public (Wufeng, 1938a: 1).

Wang never openly mentioned these suicide attempts in her writings. Perhaps she was ashamed of them, and considered attempts to end her life to be signs of weakness that were inconsistent with her public persona. In her writings, she often adopted a relatively optimistic and uplifting outlook on life, and portrayed herself as strong and independent. One of her central themes was how the oppressed should stand up on their own to fight back. In a short column entitled “We are Humans" (Women shi ren a 我們是人啊), Wang called upon her colleagues in the dancing industry to fight for the right to be regarded as human. She said that "life can be tough and oppressive. Nonetheless, one must continue to work hard" - and that working hard was the only way in which dance hostesses like her could deal with those who despised them (Wufeng, 1938e: 23). Seemingly bitter about her life at the dance hall, Wang claimed that she was sent into a "butcher's field" (tuchang 屠場), a meat market that was fuelled by plenty of whisky and jazz (Wuying, 1938a: 11).

She wrote in another column that she had only one thought on her mind when she was dancing: that she must live on in order to fight her butchers, and make them repay the bloody debt of her youth (Wuying, 1938c: 25). She wrote that the key to being mentally strong and resilient was confidence. She believed that she would not come by opportunities unless she was confident, determined and hardworking (Zhongguo yitan huabao, 1939: 3). In many ways, these writings, portraying Wang as strong, determined and resilient to cruel public forces, helped her to gain social recognition, and increased her market value as a desirable dance hostess. Creating a heroic public image was also good publicity for her.

Wang's depiction of her own patriotism helped her public image. Specifically, she was vocal about the ongoing Sino-Japanese war, and about the behaviour of some during a national crisis. She noted that she, and many other hostesses, were regular newspaper readers and that they were all familiar with the conditions of the refugees (Wufeng, 1938b: 2-3). To see people laughing gaily and dancing happily infuriated her, as she thought of her countrymen who were using weapons and shedding blood in defence of freedom. She claimed that as 
she danced, her face burned feverishly due to her foolish clients and colleagues. Then she thought about herself; she was doing the same thing, and she felt that she would be forever condemned to this kind of lifestyle (Wuying, 1938c: 25).

One way to remedy this was to contribute to the war effort. To do so, Wang became one of the main organisers of The Dance Hostesses' Entertainment Congress (Wunüjie youyi dahui 舞女界遊藝大會)一an association that provided funds for those affected by the war between China and Japan (Dianxing, 1938: 7). She campaigned for refugee relief on many occasions, and arranged a fundraising theatre production, playing the role of one of the lead characters, which she promoted in her writings (Wufeng, 1938g: 3). Commenting on this organisation, Wang thought that while they didn't have a lot of power as dance hostesses to help refugees, they had plenty of spirit, and contributions, however small, always helped (Wusheng, 1938b: 28). Showing that she was conscious of how social dancing might be inappropriate during wartime China, and presenting herself as actively trying to improve the conditions of those adversely affected by the war, helped improve her image as a patriotic dance hostess. Moreover, these kinds of patriotic self-portrayals helped members of the public to understand that social dancing was not inherently unpatriotic, and that dance hostesses could also be part of the war of resistance.

Wang was successful in her endeavours to portray herself as patriotic, despite the public backlash against social dancing as inappropriate during wartime. Many applauded her attitude towards life-her determination, desire for independence, patriotism, and hunger for knowledge. Such a portrayal of strength and determination earned her the reputation of being an "enlightened popular dance hostess" (juexing de hongwuxing 覺醒的紅舞星) (Wufeng, 1938g: 3-4). Patrons of dance halls and commentators have written articles praising Wang as an outstanding talent, an unusual woman and a role model for every woman in the country (1938g: 3-4; Yingwu xinwen, 1937: 11).

While it was generally agreed that Wang did not have the best of looks, the focus of praise, however, was often on her patriotism and determined character (Wusheng, 1938a, 7-8). Commentators argued that Wang became popular because of her inner beauty, not because of her looks or other superficial qualities. One commented that noble and respectable patrons enjoyed being 
with her because of her gentle and fluent style of conversation, as well as her healthy appearance and respectable attire. This commentator further claimed that having met hundreds of dance hostesses, he found Wang to be the most resolute and determined, and that he had never met someone so eager to learn. Such curiosity, he claimed, would lead her to a good and bright future (Wufeng, 1938d: 5-6). One commentator even praised her for spending her free time at a tutorial college (Yingwu xinwen, 1937: 11). In other words, Wang's attempts at increasing good publicity for herself were well-received by others.

Furthermore, Wang was conscious of the benefits of good publicity and the importance of writing self-portrayals as a means to promote and enhance one's reputation. Feedback was not always positive for her, and she occasionally received some criticism of her writings. One critic accused her of superficiality, implying that she was attention-seeking, and derided her efforts to organise the Dance Hostesses' Entertainment Congress as a mere attempt at self-promotion. Wang replied defiantly by arguing that dance hostesses were just as capable of defending the country, and that women like her had never dreamt of being accused of attention-seeking or self-promotion. Yet she later admitted that perhaps she, and her fellow dance hostesses, had intended to promote themselves. Even so, Wang thought that it was only within the usual limits of how people behave with regard to business strategies and plans. Moreover, she didn't think their "attention-seeking" adversely affected or injured anyone. She further claimed that publicity deserved to be credited to whoever wrote good prose, implying that she had deserved all the attention and publicity she received (Wusheng, 1938b: 28).

Besides Wang Qinzhen, other dance hostesses also wrote about their patriotic endeavours during the war. Dance hostess Li Li wrote about how she supported the war effort by starting an event entitled "dancing to save the country" (tiaowu jiuguo 跳舞救國). In this event, patrons would dance with dance hostesses and donate, while dance hostesses would also donate the money they earned to the war effort. She wrote about how women like her could not fight on the battlefield, but could raise funds or make donations, and that she too donated one day's earnings. Li claimed that this was because she could not let her country down, as she was only able to earn an income because 
of dance halls, and dance halls only existed because of her country (Rensheng xunkan, 1935a: 23).

Patriotism and treachery became the central themes of narratives about social dancing, dance halls and dance hostesses. This changing environment affected how hostess-writers portrayed themselves. Women such as Wang Qinzhen and $\mathrm{Li}$ Li thus presented themselves as determined and patriotic, as a means of mediating their existence in a changing environment that was becoming increasingly hostile to social dancing, and to dance hostesses in particular.

\section{Social Dancing Ban: The Reinforcement of Nationalist Rule and Struggles for Control}

As the possibility of a complete ban on social dancing loomed on the horizon, dance hostesses no longer considered themselves to be glamourous or even stern patriots. Instead, they depicted themselves as desperate and pitiful economic victims. After the Sino-Japanese War, a civil war broke out between the Communists and Nationalists, as China sought to deal with issues such as displaced families, refugees and hyperinflation which featured prominently in the everyday lives of ordinary people. The Nationalist government struggled for control as they faced pressing threats from the Communists who were active in bases within Nationalist-controlled areas via underground operations. To do so, the Nationalist government attempted to steer public debate and promote a frugal lifestyle for Chinese citizens as a way of gaining greater social control. The dance hostesses, meanwhile, continued to promote themselves in a way that was favourable to them.

\section{Fateful Beauties}

The continuing debate about whether social dancing was inappropriate during a time of national crisis changed abruptly from a relatively minor matter to a prominent legal and political argument after the Sino-Japanese War. As Ma Jun and Andrew Field illustrate in their research, this political and legal debate was 
triggered by a petition, from members of the People's Political Council, calling for dance halls to be banned in 1947 (Ma, 2005: 25-29). Political Council member Zhang Zhijiang (張之江 1882-1969) from Hebei headed a 46-person petition requesting that the government ban dance halls in 1946, in order to improve the moral character of society (Ma, 2005: 25-29). The petition argued that social dancing corrupted people's virtue, the fundamental quality needed to serve and defend one's country. Hence, dance halls and social dancing were posing a threat to the post-war situation, when people's livelihoods, and the stability of the country, were still uncertain. Fearing that the petition might be rejected, a revised version, which requested local governments to take discretionary measures instead of enforcing a total ban, was eventually put forward and passed (Ma, 2005: 27-28).

Dance hostesses continued to write to gain sympathy during this period. One hostess-writer, named Yao Ju 姚菊 wrote about how she was approached by a man who asked her to go to bed with him during work. She claimed that he smiled at her first, and she looked back at him flirtatiously. They began talking, and after a short while she claimed that his hand was all over her body. Yao felt embarrassed and pushed his hand away. He then proceeded to ask her to go to a hotel room with her. When she declined to do so, he was angered and left after hurling abuses at her. Yao wrote that she was very saddened by this encounter, and ended the entry by questioning why dance hostesses were getting this kind of treatment, whereby they were treated as though they were worthless (Haitian, 1947: 2).

Similarly, another dance hostess, Wu Rongrong 吳蓉蓉, also portrayed herself as a reluctant yet defiant plaything of men, and a hard worker. She claimed that dance hostesses only joined the profession in the first place because of economic reasons, and many patrons knowingly took advantage of dance hostesses for their own selfish reasons. In her newspaper column, Wu described how she encountered hypocritical men. One patron in particular appeared to be from an upper-class background, as he wore nice clothing and was well-behaved. Yet he asked her to become his mistress and offered to pay her for sexual services. Wu claimed that she was angered and appalled by his gestures. She wrote that she said to his face that he probably got his money for nothing, while she earned every penny from hard work and sweat. As such, Wu 
claimed that she was more honourable than he was. She further wrote that although she had little education, and lacked exposure and experience in society, she was a hard worker who was willing to put in the effort for financial returns. She concluded that if she had other opportunities, she would be more than happy to leave the dance hostess life (Wenfan zhoubao, 1946: 5).

More importantly, the idea that the dance hall ban might cause problems for the economy, and might have huge financial repercussions on individuals in the social dancing industry, was picked up by dance hostesses. Specifically, hostesswriters emphasised the need for them to survive and make financial contributions to their families. Dance hostess Hong Lian 泓蓮 wrote that she was extremely shaken when she first received news of the potential ban. She claimed that she immediately thought about the issue of survival, which would become the biggest problem. In her column, Hong had agreed that dance halls had now become degenerate places for young men and women, and that those who frequented them had often abandoned their careers and studies. She argued that a sudden ban on dance halls would adversely affect the lives of dance hostesses, as most of them did not possess any useful skills for reemployment. Moreover, despite yearning to improve as human beings, Hong claimed to have felt that no-one had given them any help or opportunity to advance themselves (Funü, 1947: 23).

Dance hostesses wrote letters to editors of newspapers and magazines, asking for sympathy and help, claiming that they too wanted a better life by quitting their jobs, but reality often determined that they remain employed as dance hostesses. A group of them wrote a letter to the editor of a newspaper saying that they were just a group of weak and vulnerable women who were sacrificing their youth and dignity-owing to the harshness of reality-to become the playthings of men. Moreover, the uncertainty of the future of social dancing and dance halls in Shanghai had made their lives and jobs even more difficult, resulting in them being further exploited by the owners of dance halls. These women explained that at least half of their total income was given to the owners of dance halls, or paid as tax, and the remainder was not enough to keep their families alive. Although the women wanted to leave their jobs as dance hostesses, they found it very difficult to secure alternative employment because society would not support insecure women like them (Minsheng, 1948: 18-19). 
The dilemma as to whether a dance hostess should quit social dancing is evident in other self-portrayals. Shanghai dance hostess, Zhang Kezhen 張克禎， wrote that while she thought the ban on social dancing might be a good opportunity for her to finally give up her career as a dance hostess, she also would find it very difficult to go back to her uncle's place in Changshu 常熟. The original plan had been to quit social dancing and keep house for her uncle, who sold his artwork for a living. Yet, when she had recently returned to Changshu, she had found her uncle so poor that he could no longer afford to buy drawing materials. Nor could he, wrote Zhang, find a stable job as a primary school teacher. Although she really wanted to quit social dancing, she found herself trapped in her career as a dance hostess because it could at least pay the bills (Xiandai funü, 1945: 18). When a potential national ban on dance halls was announced, there was increasing competition for attention and approval from patrons amongst dance hostesses. Their narratives, which emphasised their economic vulnerability, contributed to the overall public debate about the ban, and helped them attract public support and sympathy.

Dance hostesses used the best means at their disposal to remain employed, portraying themselves as vulnerable women. In their research, both $\mathrm{Ma}$ and Field discuss, in detail, how thousands of dance hostesses participated in a mass protest that unexpectedly turned into a violent riot on January 31, 1948 (Ma, 2005, 116 - 152; Shenbao, 1948a: 4). Unfortunately, this unforeseen event turned the public against the dance hostesses, who soon became associated with violence and destruction.

Despite this, dance hostesses continued to narrate their misfortunes even after the 1948 dance hostess riot. Some claimed that they were innocent, and attempts were made by hostess-writers to further narrate themselves as victims and weak women who were caught up in politics despite their daily struggle just to get by. A hostess-writer, named Wang 王, sought help and vented her frustration by writing to the editor of a periodical, detailing what happened to her on the day of the riot. Wang started her letter by saying that she was the most pitiful worker (zui kelian de zhiyezhe 最可憐的職業者). She said that she was a refugee who was severely affected by the war, and only became a dance hostess to support her family. Her father had been missing for some years owing to the war, while her mother was very old, and her brother was too young to 
work. Wang claimed that she went to the protest for the sake of her future, but she was only a weak woman and was wrongfully arrested by the police for being a rioter. Although she claimed that she was later released without charges, she was injured in the process, and her mother was so worried that she also became ill. Wang claimed that her family relied on the income she earned from pleasing men and making them happy, and that the ban on social dancing would have severe consequences for her and her family. She desperately wanted her voice to be heard through the publication of her letter, and wrote that it represented the little bit of hope she still had within her. By publicising the alleged injustice through her writings, Wang depicted herself as a victim, and a reluctant participant in a protest that she had no choice but to attend (Lianhe huabao, 1948: 1).

In light of other incidents of violent unrest, as well as protests and strikes that occurred during the same period, it was not difficult for the authorities in Shanghai and Nanjing to accuse the Communist Party of instigating this particular riot (Shenbao, 1948b: 4). Now dance hostesses were not only seen as morally corrupt due to their alleged decadent and extravagant behaviour, but also as unpatriotic, owing to their presumed association with the Communists, their use of violence, and their disregard for law and order. Perhaps unexpectedly, however, the government gave in to the demands of the dance hostesses, and dance halls remained open until the end of Nationalist rule in mainland China.

\section{Conclusion: Narrating the Commercial Self}

Narratives written by and about these hostess-writers add to the complex, yet rich and diverse picture of social dancing and dance hostesses during the republican period. Because of the harsh economic realities which plagued Shanghai during the 1930s and 1940s, dance hostesses had the individual and collective need to survive, and an underlying desire to gain acceptance from society. These women found themselves having to comply with the realities of being a dance hostess; they were available for hire and had to dance in close proximity to their patrons. As a result, they had to represent themselves in 
certain ways in order to attract and retain attention, as well as entice existing and future patrons to hire them.

The ways in which they described themselves changed accordingly, and they actively tried to improve their image. An investigation into the self-portrayals of hostess-writers presents them as a group of women who were more complex and proactive than was previously thought. Before the Sino-Japanese war, the women generally portrayed themselves as either desirable, consumable commodities, gaining the attention of potential customers, or as pitiful victims who deserved the public's support and sympathy. During the war, hostesswriters viewed themselves as patriotic and enlightened women, whose existence did not preclude growing nationalistic sentiments. After the war, dance hostesses went on to describe themselves as economically vulnerable women in order to gain public sympathy and remain employed. As such, these hostesses demonstrated some degree of agency in their actions, and their selfportrayals suggest that they actively attempted to mediate their existence through writing in ways that worked in their favour.

\section{Acknowledgments}

A version of this paper was presented at the 2017 Refracting Gender in Modern China workshop held at the School of Oriental and African Studies. I am grateful to Henrietta Harrison, Matthew Foreman and the two anonymous peer reviewers. Their help and ideas have influenced this paper. All errors are my own.

\section{References}

Dazhong (1944), "Yi wunü" (One dance hostess), July 1, 49 - 57.

Diansheng (1935), "Wunü zishu" (Self-description of a dance hostess)," June 7, 18.

- - (1936), "Wunü de ku shenghuo: zheshi yi ge zuo wunü de zibai” (The harsh life of a dance hostess), November 13, 30. 
Dianxing (1938), "Yige xiaojiaose de yanhougan" (Afterthoughts from an insignificant actress), April 28, 7.

Edwards, Louise (2000), "Policing the Modern Woman in Republican China", Modern China 26(2): 115-147.

Field, Andrew David (2010), Shanghai's Dancing World: Cabaret Culture and Urban Politics, 1919-1954, Hong Kong: The Chinese University Press.

Funü (1947), "Yige wunü duiyu jinwu de yijian" (A dance hostess's opinion on the dancing ban), October 20, 23.

Funüjie (1941), "Wunü riji” (Diary of a dance hostess), August 20, 19-20.

Haitian (1947), "Dadan de zigong: wunü riji" (A bold confession: the diary of a dance hostess), February 17, 2.

Lee, Leo Ou-fan (1999), Shanghai Modern: The Flowering of a New Urban Culture in China, 1930-1945, Cambridge, Mass.: Harvard University Press.

Lianhe huabao (1948), "Wunü huyuan" (Dance hostess cries for her innocence), March 1, 1.

Ma, Jun (2005), 1948 nian: Shanghai wuchaoan (1948: The Shanghai taxi dancers' riots), Shanghai: Shanghai guji chubanshe.

Minsheng (1948), "Duzhe toushu: yiqun wunü de husheng" (Letters from readers: cries from a group of dance hostesses), October 10, 18 - 19.

Rensheng xunkan (1935a), "Wunü riji (vi)" (Diary of a dance hostess (one)),25 July, 23.

- - (1935b), "Wunü riji (er)" (Diary of a dance hostess (two)), 25 August, 14.

Shanghai Municipal Archives, U (Zujie dang'an 租界檔案), Y (Zhongwen dang'an 中文檔案), D (Geming lishi dang'an 革命歷史檔案), Q (Minguo dang'an 民 國檔案), B (Zhengfu xitong dang'an 政府系統檔案).

Shen, Bojing (1934), Shanghaishi zhinan 上海市指南 (A guide to Shanghai city), Shanghai: Nanfang zazhishe chubanbu.

Shenbao (1927), "Bali Tiaowuting jinri kaimu” (Black Cat Cabaret opens today), December 22, 1.

- - (1938a), "Choutai bilu Shanghai dibing danao Bailemen gaoju” (Ugly state revealed, Shanghai enemy soldiers wreak havoc at the Paramount), 16 January, 2.

- - (1938b), "Shanghai lun wei gudao hou yulechang fan fada" (Entertainent venues flourish despite Shanghai becoming a lone island), November 6, 10. 
- - (1943), "Wan yu qingnian xuesheng zuo qingyuan youxing" (Approximately ten thousand youngsters protested on the streets yesterday), December 28, 3.

- - (1948a), "Wuye fandui jinwu dabaodong" (Dance industry instigated riot against dancing ban), February 1,4 .

- - (1948b), "Ge shouzhang shangtao duice" (Leaders discuss countermeasures) February 1, 4.

Shidai (1939), "Zai zhe yang de qingxing xia wo renshi le zhe wei wuguo di yi zhi bi: hongxing Wang Qinzhen xiaojie" (I met the best writer in the world of dance under these circumstances: popular dance hostess miss Wang Qinzhen), February 1, 41-42.

Shiritan (1934), "Yige wunü de zishu" (A self-description of a dance hostess), March 20, 14.

Stevens, Sarah E. (2003), "Figuring Modernity: The New Woman and the Modern Girl in Republican China", NWSA Journal 15(3): 82-103.

Tanxing nülang (1936), "Wang Qinzhen xunjie weiguo" (Wang Qinzhen fails to die for her loved one), July 23, $13-14$.

Tianwentai (1936), "Wunü zishuji" (Self-description of a dance hostess), December 30, 3.

Wang, Changnian (1947), Dashanghai zhinan 大上海指南 (Great Shanghai Guide), Shanghai: Dongnan wenhua fuwushe.

Weinbaum, Alys E., Lynn M. Thomas, Priti Ramamurthy, Uta G. Poiger, Madeleine Y. Dong and Tani E. Barlow (eds.) (2008), The Modern Girl Around the World: Consumption, Modernity, and Globalization, Durham: Duke University Press.

Wenfan zhoubao (1946), "Wunü de zibai" (Confessions of a dance hostess), September 7, 5 .

Wode huabao (1939), "Yige wunü de zishu" (A dance hostess' self-description), June 5,5 .

Wufeng (1938a), "Wang Qinzhen tu yu zuowan fudu wen: yidai hongxing, hongyan boming" (Wang Qinzhen abruptly took poison last night: A popular star of an era, a beautiful woman who suffers from an unhappy fate), June $25,1$.

- - (1938b), "Wunülei ju zhong ren fangwen ji" (An interview with those from the Tears of a Dance Hostess), June 25, 2-3. 
-- (1938c), "Wunülei juzhongren yuyan suobi: Wang Qinzhen xiaojie (Remaining words and occasional jottings from actress of Tears of a Dance Hostess: Miss Wang Qinzhen), June 25, 5.

-- (1938d), "Juexing de hongwuxin: Wang Qinzhen lun" (The awakened popular dance hostess: comments on Wang Qinzhen), July 5, 5-6.

- - (1938e), "Women shi ren a" (We are humans), July 5, 23.

- - (1938f), "Gei jiemeimen de yifeng gongkaixin" (A public letter to my sisters), July $5,28$.

- - (1938g), "Wuxing xiexiang: Wuguo de di yi zhi bi: Wang Qinzhen" (A portrayal of dance stars: the best writer in the world of dance: Wang Qinzhen), August 11, 3-4.

- - (1938h), "Sheng zhi gechang" (The singing of life), August 11, 22.

- - (1938i), "Wuguo jinchai sanshiliu" (Thirty-six gold hairpins of the world of dance), September 1, 10.

Wusheng (1938a), "Wunüjie youyi dahui de faqiren Wang Qinzhen de shenshilu" (The biography of the founder of the dance hostess's entertainment congress), May 16, $7-8$.

- - (1938b), "Wunü buneng jiuguo ma" (Can't dance hostesses save the country), May 16, 28.

Wuying (1938a), "Wode zibai: duiyu di yi zhi bi de bianbai" (My confession: In defence of being the best writer), October 1, 11 .

- - (1938b), "Wuye jingzheng de bairehua" (Competition in the dance industry becomes increasingly fierce), October 1, 9 - 10.

- - (1938c), "Kuwei zhong de suibi" (Occasional jottings in the midst of bitterness), November 1, 25.

Xiandai funü (1948), "Yige wunü de zishuxin" (A letter of self-confession by a dance hostess), February 1, 18.

Xiaojie (1937), "Wunü de zishu" (A self-description of a dance hostess), April 10, 14.

Yingwu xinwen (1935), "Sangfu shi pinyi hangou renru bei ren qin yi ge wunü beitong zishu" (A dance hostess's heartbreaking confession: husband dead and support lost, utterly humiliated and raped), September 29, 7.

- - (1937), “Xiaoyao Wang Qinzhen dique shi bupingfan nüzi (Liberty's Wang Qinzhen: indeed an unusual woman), March 27, 11.

Yule (1935), "Yiwei wunü de zishu" (A dance hostess' self-description), November 10, 465. 
Zhongguo yitan huabao (1939), "Women yao you zixin" (We need to have confidence), August 21, 3.

Amanda Zhang is a PhD student in the Faculty of Oriental Studies at the University of Oxford. 